\title{
Din Sosyolojisi*
}

WINSTON DAVIS

ÇEVIREN: IHSAN ÇAPCIOCILU

AR. GÖR, ANK ARA Ü. ILAHIYAT FAKÜLTESI

e-mail: icapci@divinity.ankara.edu.tr

\section{Giriş}

Din ve toplum arasındaki ilişkilerin sistematik ve objektif olarak incelenişi, Socidogie kelimesini ilk defa kullanan Auguste Comte'dan (1798-1857) çok önceleri mevcuttu. Xenophanes (M.Ö.560-478) Habeşistanlı Tannlann siyah ve küçük burunlu, Trakyalı olanlann ise, hafif mavi gözlerle birlikte kızl saçlı olduklanna dikkat çekerken zaten din sosyolojisi disipliniyle yüzeysel bir şekilde de olsa ilgilenmiş oluyordu. Benzer bir şekilde, Müslüman felsefeci İbn Haldun (1332-1406) Mukaddime ya da Kitabu'libere (Dünya Tarihi) girişte, Kuzey Afrika Krallıklannun yükseliş ve düşüşlerinde dinin rolünü incelerken sosyal dayanışma (asabriyze) kavramıla yakından ilgilenmişti. Modern zamanlarda, klasiklerle ilgilenenler, dinler tarihçileri ve "seküler" tarihçiler kuşkusuz din araştırmalan alanunda profesyonel sosyologlardan daha çok ve muhtemelen daha iyi yazmaktadırlar. Bir disiplin olarak sosyolojinin gerçek gücü, onun kapsamlı ya da evrensel öneme sahip tutarlı bir yaklaşım geliştirmek amacıyla modelleri, teorileri ve son zamanlarda istatistiksel yöntemleri daha açık bir şekilde kullanmasında yatıyor gibi görünmektedir. Daha ideografik bilim anlaysşlannın aksine din sosyolojisi, din ve toplumu nomotetik bir şekilde yani, yasaların birbirine bağlı düşünce, duygu ve davranış ağlan ya da sistemleri gibi inceleyerek ün kazanmıştır.

Modern zamanlarda sosyolojik din araştırmalanının ortaya çıkışı, kapitalizm, kültürel çoğulculuk, dinsel hoşgörü ve liberal devletin yükselişi ile yakından ilişkilidir. Bu nedenle, bu disiplin din ve toplumu "doğal" bir halde irdelediğini iddia edemez. Aksine bu disiplin, araştırmacıların inceledikleri dinler ve toplumlar tarafindan ortaya atılan normatif iddialardan kendilerini

- "Sociology of Religion", The Encydopedia of Religion içerisinde, Mircea Eliade (Editör), Volume 13, Macmillan Publishing Company, New York, 1987: 393-402. 
uzaklaştırmalanna imkan sağlayan ya da onlan buna zorlayan Batı sosyal düşüncesindeki eşsiz tarihsel gelişmeler tarafından üretilen kültürel bir üründür. Aslında din sosyolojisi, kendi doğurgan ilgilerinden birinin, yani, dini düşünce ve kurumlann sekülerleşmesinin ürünüdür. Din sosyolojisinin aksine, dini sosyoloji, teoloji ve kurumsal din -özellikle Fransa ve Belçika'da Roma Katolik Kilisesi- ile daha yakın ilişkiler kurmaya çalş̧maktadır.

Din sosyolojisinin tarihi ana hatlanyla dört döneme ayrlabilir: Geleneksel sosyal düşünce, şüphecilik ve spekülasyon, muhafazakar ve romantik tepki ve modern sosyal teori.

\section{Geleneksel Sosyal Düsünnce}

Modern sosyoloji şekillenmeye başladığında ilk olarak dönüştürülen ve dünyevileştirilen düşünce yapisı, geleneksel sosyal düşünce olarak adlandınlabilir. Bu, birleşik bir düşünceler sistemi olmadığ gibi, birbirinden farklı ve hatta birbiriyle çelişen unsurlar içeriyordu: Platoncu idealizm, Aristocu teleoloji, Stoacı tabii hukuk, Augustinyenci sosyal realizm ve ortaçağ bilim adamlannun çeşitli sosyal teorileri. Geleneksel sosyal düșünceyi özellikle karakterize eden şey, onun sosyal ve etik analizlerin sentezinden oluşmasıydı. Çïnkü tabiat gibi toplumun da bir gayesinin ya da amacının olduğu düşünülüyordu. Geleneksel sosyal düşünce döneminde sosyal analizin "olan"1, değerlerin "olması gereken"inden aynlmamışt. Huristiyan çevrelerde sosyal kurumlann incelenmesi, bütünüyle kilisenin amaçlan doğrultusunda yapllyordu. Geleneksel sosyal düşünce, bütün kurumsallaşmı̧s sosyal değerlerin ve kurumlann kozmolojik ve ilahi kaynaklan üzerinde durdu. İnsana sosyal ve siyasal bir varlık gözüyle bakan bu düşünce, gerçek "kamu yaran" nın varlığının "sağlam akl"a sahip herkes tarafından bilinebileceğini ve iyi niyet sayesinde uygulanabileceğini savundu. Diğer dinler gibi Huristiyanlık da söz konusu kamu yarann, toplum ve evreni bir ve aynı gören aşkın nesneler düzenine göre tanımlad. Geleneksel sosyal düşüncenin ana akımı, toplumun organik birliğini tabï hukuk diliyle ifade etti. Bu teoriye göre, kurumlar, tabiata bizzat Tann'nın koyduğu kurallan yansıttıklan oranda sadece mitolojik açıdan meşruiyet kazanmakla kalmaz- ayn zamanda felsefi açıdan da haklı gösterilebilir ya da mahkum edilebilirlerdi.

Geleneksel sosyal düşünce, din sosyolojisine bazı temel kavramlanın miras bıraktı: Toplum, din, zorunluluk ve varlığın temel düzeni ya da yasası. Seküler bir kavram olarak değiştirilen sosyal düşüncenin tabï hukuk kavram, erken dönem doğa bilimlerinin ve sosyal bilimlerin temelini olușturmuştur.

* Başlıklar mütercim tarafindan numaralandırimışıtır. 


\section{2. Şüphecilik ve Spekülasyon}

Ortaçağlarda ve Rönesans'ta kuramcilarn aradığı toplumun yasal düzeni, insan $1 \mathrm{rkın}$ spiritüel/manevi mükemmelliğe çağıran bir düzendi. 17 . ve 18 . yüzyllarda düsünürler düzen arayşların devam ettirdi. Ancak artık onlan ilgilendiriyor gibi görünen bu düzen, bazı basit, doğal standartlara göre dillerin, örf ve adetlerin ve dinlerin çeşitliliğini açıklayabiliyordu. Bütün bunlar içerisinde aklın oynadığı rol, özellikle empiristler gibi bazı gruplar tarafından kü̧̈ümsenirken, rasyonalistlerin de aralannda bulunduğu bazılan tarafindan abartllyordu.

17. ve 18. yüzyllarda geleneksel sosyal düşünce entelektüel saldırlara maruz kaldı ve -1960 'da Richard Hooker'n Of the Law of Ecolesiastical Polity adlı eserinin yaynlanmasından sonra- gittikçe savunmaya çekildi. Artuk geleneği savunanlardan daha fazla dayanışma içerisinde olan muhalifler arasında çok sayıda Rönesans ve Aydınlanma düşünürü yer alyyordu: Niccolo Machiavelli ve Thomas Hobbes gibi politika eleştirmenleri, Bernard Mandeville gibi hicivciler, İtalyan hukukçu Giovanni Battista ve Fransız ve İskoç aydınlanmassının felsefecilen (Crane Brinton'a göre daha doğru ifadesiyle soxyologlan). Geleneksel sosyal düsünncenin söz konusu kritğinin ardındaki entelllektuiel ilham kaynaklan da, oldukça farklydi. Bunlar, Isaac Newton'ın mekanik felsefesi, René Descartes'n insan merkezli epistemolojisi, Francis Bacon'in empirisizmi (ve teleoloji aleyhtan yazilan) ve gerek toplumu gerekse ekonomiyi daha "gerçekçi" yani, daha az dini ya da ahlaki temeller üzerine inşa etmeyi amaçlayan çeşitli spekülatif düşünce sistemlerini içeriyordu. Ulus devletin yükselisii ile sosyal ve ekonomik teori hakkında söz söyleme yetkisini din adamlarnndan devralan, toplumun yeni üyesi tüccar ya da burjuva sınıfının doğuşu, aynı derecede önemliydi.

\subsection{Tabii Hukuk'a Saldırı}

Burjuvazinin sözcülüğünü yapan ve sanayi devriminin zaferini ilan eden bazı 17. yüzyl düşünürleri, geleneksel tabii hukuk kavramı aleyhine bir saldın başlattlar. Her ikisi de Protestan Kilisesine üye olmayan Hugo Grotius ve Samuel Pufendorf, tabii hukukun Tanr'dan bağımsı olarak varolabileceğini savundular. Thomas Hobbes biraz daha ileri giderek tabii hukuku "barnşı sağlamaya yönelik maddelere" yani, basit ve çıkarcı bir aygita indirgedi. Onun ele aldığı "tabiat" ilahi bir düzenin değil, aksine güvensizliğin psiko-biyolojik doğasının ve geleneksel sadakat ve bağlllk iliskilerinin artık bir arada tutmayı başaramadığı bir dünyada yaşayan "sahipsiz insanlığın" bir yansımasıydı. Hookers' in gelenekselciliğine sınırsz saygı duyuyor gibi görünen John Locke bile, tabiat kanunlarnn sadece "bir anlama aracı" olduklarnn kabul etmek zorunda kaldı. Çoğunlukla mülkiyet haklanınn kutsallaştınlacağını taahhüt 
eden bu felsefi çabalar, tabii hukuk kavramını dünyevileştirdi ve sınırların hukuk biliminden ahlak felsefesine kadar genişletti. Bütün bu gelişmeler sosyal bilimlerin ortaya çıkışına zemin hazırladı.

18. yüzyl boyunca seküler ya da "aydın" görü̧̧lü yazarlar pek çok sosyal kötülïuğün sorumlusu olarak dini ve batıl inançlan gördü. Anti-klerikalizm (ruhban sınıfı karşıtlı̆ı) neredeyse bütün sosyal eleştirilerin rutin bir özellĭgi haline geldi. Dinin Avrupalılann yaşamındaki kronikleşmiş sonunlan hafifletmeyi başaramadığına inananlar, sosyal düzenin yeni kaynakların ortaya çıkarmak için bir araştırma başlattlar. Sonuçta toplumun önceden belirlenmiş ilahi takdire ve tabii hukuka göre yapılandırlması gerektiğini savunan geleneksel görüş, yerini, toplumun insanun kendi “yetenekleri” ya da "planlan" tarafından yapılandınldığını ya da yapılandırlması gerektiğini savunan görüşe bıraktı. Böylece modem dünyanın felsefi ve sosyolojik teorilerinden çoğuna kaynaklik edecek olan seküler, sosyal hümanizm ortaya çıkmaya başladı. Daha zengin ve daha güvenli bir toplum yaratmak amacıyla Hobbes, Mandeville, d'Holbach, Halvétius, Spinoza ve Hume gibi düşünürler önceleri geleneksel sosyal düşünce tarafından basturlan ya da kontrol altunda tutulan kişisel çıkar ve bencillik gibi duygulan işlevselleştirmenin ya da maniple etmenin yollannı aradılar.

$\mathrm{Bu}$ spekülasyonun en önemli sonuçlanndan biri, bugün sosyal sistemler olarak adlandırlabilecek yapının keşf edilmesiydi. Bu dönemde düşünürleri büyüleyen şey, -din, ahlak ya da devletin müdahalesi olmaksızın- düzen ve gelişmeyi "kendiliğinden" meydana getirecek olan tüzel etkileşim ağlannın kurulabilmesiydi. Sosyal sistemler görüşü edebi eleştiri ve sosyal yergiye çok şey borçludur. Bu görüş, 18. yüzylın başlannda, "kişisel zaaflann" doğru bir şekilde işlenmesinden kaynaklanan "kamusal çıkarlar" üzerine hararetli yorumlanyla tanınan Bernard Mandeville tarafından savunuldu. Bu yüzyllen sonlannda Adam Ferguson geliştirdiği tanımla bu kavramı daha da genişletti. Ona göre kunumlar, "herhangi bir beşeri planın idarecisi değil, aksine beşeri faaliyetin sonucudurlar". Adam Smith bu görü̧ü kısa süre içerisinde Batı sosyal düşüncesine egemen olacak terimlerle açıkladı: "Sistemler pek çok açıdan makinelere benzer". Zaman ilerledikçe sosyal düşünce tarafından geliştirilen -mekanik, organik, sibernetik ve nihayet semiotik- sistemlerden her biri birbiri ardınca sosyolojik din analizlerinde kullanulabilmiştir.

Daha şüpheci meslektaşlannın aksine Smith, ekonomik ve ahlaki sistemlerle ilgili görüşlerini (ünlü ve etkili "görünmeyen el” görüşü gibi) israrla tabï hukuk ve ilahi takdire dayandird. Locke'un siyaset felsefesi ile birlikte Smith'in ekonomisi, 20. yüzyl boyunca Anglo-Sakson Dünya'da filizlenip gelişecek olan dinsel hoşgörü, siyasi liberalizm ve kapitalizmin eşsiz sentezine temel oluşturdu. Bu kültürel sentezin başansı, muhtemelen, Büyük 
Britanya ve Kuzey Amerika'da din biliminin Kita Avrupa'sınin sosyal düşüncesinden daha az anti-klerik ve anti-dini olmasının nedenini açıklamaktadır.

\subsection{Din Sosyolojisinin Doğuşu}

Din sosyolojisinin doğuşu muhtemelen bu bunalımlı zamanda, yani -20 . yüzyl ekonomisti A. Schumpeter"in ifadesiyle- "laik sosyal bilimin", tabï hukuk kavramını sosyal ve ekonomik fenomenlere uygulamaya başladığı bir dönemde gerçekleşti. Ampirik bir yaklaşım kullanuldığı iddia edilmesine rağmen, bu dönem boyunca din araştırmalarının çoğu, sadece spekülasyon yoluyla yantlanabilecek sorular sorarak dini inancin tarihsel ya da psikolojik kökenleri üzerine yoğunlaştı. Genellikle bu etki, dini; iklim, korku, cehalet ya da kilisenin aldatmacası gibi çok daha açık bir gerçekliğin bağımh bir değişkenine indirgemeyi amaçlyyordu. Erken dönem din sosyolojisi (ve sosyal psikoloji) ile ilgili en parlak, fakat hala spekülatif denemelerden biri, bizzat Adam Smith tarafindan yazilan Wealth of Nations'dur. Burada ekonomik rekabet ve psikolojik onaylama kavramlann dini rekabet sorununa uygulayan büyük ekonomist, dini çoğulculuk teorilerinin en erken örneklerinden birini üretti.

Aynca, dinin sosyal kontrol konusundaki rolünün analizi, bu dönem biliminin din sosyolojisine değerli katkular arasındaydı. Bu alanun öncüleri arasında din ve hukuk arasındaki ilişkileri inceleyen Montesquieu (CharlesLouis de Secondat) ve din ve sosyal değerlerle ilgilenen Mondeville saylabilir. Şüphecilik ve spekülasyon çağının muhtemelen en önemli katkısı, bu dönemde sekülerleşme kavramının aynntlı bir şekilde ele alınup incelenmesiydi. 18. yüzyıl yazarlannın pek çoğuna göre, dinin düşüşü ilerleme düşüncesinin doğal bir sonucuydu. Çoğunluk bilimdeki ilerlemeler ve aydınlanma ile birlikte dinin ve hurafelerin kaçınılmaz bir şekilde aklın güçlerine boyun eğeceğine inanyordu. Çünkü, din, sosyal kurumlar, bilim ve teknolojideki değişmelenin birbirleriyle yakından ilişkili olduğu düşünülüyordu. Anlaşılan herhangi bir alanda meydana gelen değişmelerin diğer alanlara da yansıması son derece doğaldı. Üstelik, (sadece J. G. Herder, Jean-Jacques Rousseau gibi çok az sayda düşünürün karşı çıktiğı) gelişim kanunlarınun sözde evrenselliğinden dolay, tarihsel ilerleme ve bir ulusun sekuilerleşmesi, diğerlerinden her hangi birinin değişimi açısından geçerli bir paradigma olarak kabul edilebiliyordu. Bu varsayımlar, sekülerleşme sürecinin bizzat tabiat kanunlan kadar şüphe götürmez olduğunun kabul edilmesine katkıda bulundu.

Şüphecilik ve spekülasyon çağının düşünürleri, geleneksel sosyal düşüncenin en kesin inançlanından bazllanna meydan okudu. Bu düşünürler, 
geleneğin hukuk, ahlak ve kurumlara tahsis ettiği ilahi kaynaklann yerine toplumun geleneksel doğası üzerinde durdular. Gelenek, toplumu doğal ya da kutsal kalıplara uydurma görevini "sağlam akla" verdiği halde, David Hume "aklın ihtiraslann kölesi olduğunu ve öyle kalması gerektiğini" savundu. Geleneksel düşünürler tarafından öğretilen kamu yarannın teleolojisi, "sonuçsuz bir çaba" (Mandeville'in ifadesiyle) olarak görüldüğü için kabul görmedi ve sonuçta yerini faydacı felsefe, Kanţ̧ı bireycilik ve sosyal ve ekonomik sistemlerin "kendiliğinden" -yani, devlet, din ya da ahlakın doğrudan desteği olmaksızın- işleyebileceğine dair inanca bıraktı. Bu nedenle, bu çağın septik felsefecileri, kutsal ve sosyalin klasik sentezini ortadan kaldırmanın yollannı aradılar. Onlanı özerk ve seküler bir ahlak inşa etmeyi amaçlayan çeşitli girişimleri, dini, insanlığın işlerinde sadece değersiz -ya da olumsuz- rol oynayan bir konuma terk etmiş gibi görünüyordu. Böylece ilk defa ahlakç̧lanı alanı ahlak bilimcilerin (moraliste) yani, sosyal değerlerin tarafsız gözlemcilerinin alanından aynılmış oldu. Ahlak bilimcilerin dini inanç ve bağlliklarla ilgilerini kesmeleri, daha sonralan dine sosyal-bilimsel yaklaşımın ayırt edici niteliklerinden biri haline gelmiștir.

\section{Muhafazakar ve Romantik Tepki}

Spekülasyon özellikle dinin kaynağ1 ya da "doğanın durumu" konusunda insanın temel yetenekleri ile ilgili boş tartışmalarla sonuçlandığında, bu çağın empirisizminin düğümünü çözmüs oldu. Sanayi devrimi ve Fransız Devriminin (ve onu izleyen terör ortamını) ortaya çıkardığı büyük tahribat, insanın kendi toplumunu sadece kendi yetenek ya da beceriler sayesinde inşa edebileceği ya da geliştirebileceğine dair aydınlanmanın iyimser inancının sorgulanmasına yol açtı. Hemen ardından gelen muhafazakar ve romantik tepkiler, gerek dine gerekse topluma yönelik tutumlan kayda değer bir şekilde değiştirdi.

Romantikler, sanayi devrimi ve Fransız Devriminin bireyler ve toplumlar üzerinde ortaya çıkardiğı aşın hümanist sonuçlardan yakındılar. Aynca onlar - Volksgeist ve Volkssede ("ulus ya da halklarnn ruhu ve canlliğı") ile ilgili tartş̧malannda geniş rol oynayan- dinin, artık, geçmişin sıradan bir hurafesi olarak kolayca göz ardı edilemeyeceğini savundular. Diğer taraftan muhafazakarlar, toplumun bireysel mühendisliğin yapay bir ürünü olmadığın, aksine bireyin toplum ve toplumun Tann tarafından şekillendirildiğini ısrarla vurguladılar. Aslında onlar, toplum, din, gelenek, otorite ve birey arasındaki karşllklı organik ilişkileri yeniden keşfetmişlerdi. Louis de Bonald (1754-1840) ve François René de Chateaubriand (17681848) gibi muhafazakar düşünürlere göre din, artık, sadece bir dogma ya da inanç konusu değildi. $\mathrm{O}$ sosyal bir fenomendi de. Monarşistler ve aristokrasi 
sözcüleri gibi onlar da kişisel çıkann sosyal düzeni kendiliğinden üreteceği fikrine karşı çıktılar. Bonald, Friedrich Karl von Savigny (1779-1861) ve Justus Möser (1720-1794) ile birlikte, 18. yüzyl tabï haklar öğretisinin ima ettiği çağdaş tabï hukuk ve bireycilik teorilerinin soyut evrenselciliğini eleştirdi. Onlann nazarında bu öğretiler Avrupa uygarlı̆̆ını deforme eden siyasal ve endüstriyel devrimlerin felsefi ürünleriydi. Muhafazakarlar, SaintSimon ve Durkheim'in görüsslerine nüfuz ederek dinle ve dinin kurumlann oluşumu ve bireyin yaşamında oynadığı rollerle ilgili müteakip tartışmalan derinden etkilediler. Onlann çalışmalan, daha sonralan dinin bütünleştirici ya $\mathrm{da}$ dengeleyici işlevi üzerinde duran sosyologlann ilham kaynağ 1 oldu. Onlann, dini, birey ve devlet arasunda bir arac1 kurum (conps intermediaire) olarak ele almalan, Durkheim'den Peter L. Berger'e kadar sosyologlann aracı kurumlar, aracı yapılar ve kurumlar konusundaki tartışmalarında yeniden gündeme gelecek bir konuydu.

\section{Modern Sosyal Teori}

Modern sosyal teorinin gelişimi, sosyolojinin seküler temellerinin daha iyi anlaşılması, salt spekülasyonun ötesine geçme konusundaki kararllik, alan araştırmalannda empati ve tarafsılık arasındaki gerilimin profesyonelce işlenmesi, din araştırmalann genel sosyal bilim teorileri ve modelleriyle ilişkilendirmeyi amaçlayan sofistike çabalar ve maddecilik, indirgemecilik, davranış̧llk, pozitivizm, evrimcilik ve dini sembollerin yorumlanması üzerine süregelen tartışmalar tarafından karakterize edilmektedir. Felsefecilerin kilise aleyhtan şiddetli tartışmalan, dinin sosyal dayanışmanın sürdürülmesi ve sosyal değişmenin sağlanması konusundaki rolünün oldukça tarafsız bir şekilde analiz edilmesiyle sonuçland.

Modern sosyal teori, aslında, 18. yüzylda David Hume, Adam Ferguson, Adam Smith ve İskoç Aydınlanması ile başladığı halde, bugün çoğu sosyolog sosyolojinin kökenini Claude-Henri de Rouvroy, Comte de Saint-Simon (1760-1825) ve onun eski sekreteri Auguste Comte (17981857)'a dayandırmaktadır. Gerçekten de sosyoloji bu iki Fransız'a çok şey borçludur. Sosyoloji mitolojik karakterini, Auguste Comte'un eserleriyle ve özellikle tarihi; dinsel, metafizik ve bilimsel evrelerle açıklama iddiasında olan evrimci şemasıyla keşfetti. Comte sonrası gerek Marksist gerekse liberal düşünürlere göre, dinin düşü̧̧ü, ilerlemenin kaçınlmaz sonucu ve sosyal bilimlerin ve doğa bilimlerinin bir aksiyomu olarak kabul edilmiştir. Herbert Spencer, ahlaki emirlerin kutsal kökenlerini yitirdiklerinden dolayı, değerlerin zamanla sekülerleşmesinin kaçınılmaz olduğunu dogmatik bir dille ifade etti. Sekülerleşme tartışması, başlangıçtan beri, aşın kavramlarla yürütüldü. Bazılan - Weber, Marks ve Sorokin dahil- dinin düşüşünün önlenemeyeceğini 
savundu. Yakın zamanda, Talcott Parsons, Robert N. Bellah, Mary Dauglas, Thomas Luckmann ve diğerleri, sekülerleşmenin kesinlikle mümkün olmadığın iddia etti. Amprik verilerden hareketle daha ihtiyatlı davranan bazı bilim adamlan ise, toplumun belirli alanlarunda dinin gerileyebileceğini ya da ortadan kalkabileceğini, ancak "sekülerleşme"nin kesinlikle evrensel, kaçınulmaz ya da tersine çevrilemez bir "süreç" olmadığına dikkat çekti.

\section{1. Émile Durkheim in Katkıları}

Modern dönem din sosyolojisinde aslında sadece iki büyük şahsiyet vardır: Émile Durkheim ve Max Weber. Onlar görüşlerinin teorik açıdan bütünleştirilmesi görevini başkalanna bırakarak bu alanın problemlerini ve parametrelerini ortaya çıkarmıslardır. Durkheim, sadece Saint-Simon ve Comte'dan değil, aynı zamanda W. Robertson Smith'in semitik dinle ilgili yazilarindan ve klasiklerle ilgilenen hocası N. D. Fustel de Coulanges'in görüşlerinden de etkilenmiştir. Durkheim'in din sosyolojisine en önemli katkısı, kollektif bilinç (conscience oollective), kollektif ahlaki bilinç ve sosyal bilincin doğusunda dinin oynadı̆g rolü analiz etmesiydi. $O$, dinin modern yaşamda oynadı̆ı̆ en kuiçük rolün bile sınırlandırıldığına dair dönemin yaygın kanaatini paylaştığı halde, dinin gerilemesi üzerinde değil, onun değişimi üzerinde yoğunlaştı. O modern toplumlann dinine "birey kültü" adını verdi.

Durkheim'in bu kavramı analizi, modern sosyolojinin, örneğin, Thomas Luckmann'ın "görünmeyen din"i, Talcott Parsons'in "dinin özelleşmesi" ve Robert N. Bellah'ın "sivil din"i gibi dindarhğın çeşitli şekillerine yönelik yaygın ve kurumlar üstü ilgisinin önünü açtı. Bir "sivil din teologu" olarak Durkheim -bir zamanlar Bellah onu böyle nitelendiriyordu- modern sanayi toplumunda karşlaştı̆̆ açgözlü bireyciliğin açtı̆̆ı yaralan sarmak için sosyolojiyi kullanyordu. Ahlakçluğına, özgeciliğe olan saf inancına ve geleneksel sosyal düşünce içerisinde kökleşmiş gibi görünen kurumlarla ilgilenmesine rağmen, Durkheim öğretisinin en temel özelliğĭ, bütünüyle seküler olmasıydı. Hıçbir dinin yanlığlğın kabul etmemesine rağmen, Durkheim'e göre ilahiyat, "biçimi değiştirilmiş ve sembolik bir dille ifade edilmiş toplum"dan başka bir şey değildi. Onun din analizi, dini sembollerin anlamı ya da içeriği (kutsallığı) ile dinin fonksiyonlanndan biri (toplumu bütünleștirmesi) arasındaki temel bir karssıklığa dayanyordu. Bu kanşıklık, onun, dinin bozucu ya da parçalayıcı özelliğini küçümsemesine, buna karşın sosyal dayanışmayı sağlayıcı rolünü fazlasıyla abartmasına yol açtı.

Durkheimci din sosyolojisinin güçlü ve zayff yönleri fonksiyonalizm ekolü tarafından miras alındı. A. R. Brown, Bronislaw Malinowski ve diğerlerinin katkılanyla biçimlendiği şekliyle fonksiyonalizm, dini, sosyal sistemin bütününe ya da psiko-biyolojik mutluluk ve bireyin bütünlüğ̈üne 
katkısına göre yorumlamayı denedi. Fonksiyonalistler, tıpkı 18. yüzyıldaki septik selefleri gibi, dinin (korkuyu azaltucı fonksiyonu gibi) psiko-sosyal fonksiyonlan hakkında oldukça spekülatif yorumlar geliştirdiler. Örtülü teleolojisinin totolojik anlamsızloğ eleştiri konusu olsa da -ki bununla din, neredeyse bütünlestirici fonksiyonuna indirgeniyordu- fonksiyonalizm, bugün din sosyolojisine apaçık bir teori olarak olmasa da, kazanılmış bir bilgi olarak nüfuz etmeye devam etmektedir.

\subsection{Alman Biliminin Etkileri}

Dinler tarihi (Religionsgesdidhte) ve kültür bilimlerinde (Geisteszeissensdzaften) Alman bilim adamlan, Comte, Spencer ve E. B. Tylor'ın sınurl bilișsel yaklaşımlanının çok ötesine uzanan dini kavramsallaştırma şekilleri geliștirdiler. Friedrich Schleiermacher (1768-1834) dinin bilgiden çok duygu (Gefuib) ile temellendirilmesi üzerinde durdu. Sonuç olarak, din, dünyays "anlama"ya yönelik iptidai bir çabadan daha fazlası olmaliydı. Schleiermacher'in etkisi altında çalı̧̧maların sürdüren Wilhelm Dilthey (1833-1911), dinin eșsiz doğasının ya sempati ile ya da din sosyolojisinde daha sonra Max Weber tarafından geliştirilecek önemli bir yöntem olan içeriden anlama (Verstehen) ile anlaşılması gerektiğine işaret etti.

1917'de Rudolf Otto yeni bir çağa ait eseri The Idea of Holyde, Kant'dan bu tarafa dini tecrübeyi ahlaka indirgemeye çalsşan Protestan liberalizmine öncü bir saldır başlattı. Otto, bütünüyle farklı bir şekilde, dinin özünün, kutsalla kanş̧1k dehşet, korku ve büyü öncesine ait tecrübeler olduğunu gösterdi. Kutsal, dünyayı "anlama" çabasının çok ötesinde hem cezbeden hem de korku uyandıran gizemli bir tecrübeydi. Otto, ona msterium tremendum et fascinosum adını verdi. Alman teolojisi ve din araştırmalanndaki bu gelişmeler, o dönemde Avrupa'nın büyük bölümünde yaygın olan din anlayışından çok daha sofistike ve sempatiye dayalı bir anlayşın önünü açtı.

Almanya'da din sosyolojisine en önemli katkılar, Ernst Troeltsch (18651923) ve Max Weber (1864-1920)'den geldi. Immanuel Kant, G. W. F. Hegel, J. G. Fichte, Friedrich Schleiermacher ve Albrecht Ritschl'n başın çektiği felsefi ve teolojik gelenekler üzerinde çalı̧san Troeltsch, dinler tarihinde manevi ve maddi güçler arasındaki karşılıklı etkileşime dikkat çekti. $O$, Hiristiyanlik tarihinde, dünyayla banşı yaşamayı arzulayan hareketler ve kurumlar ile bunu kabul etmeyenler arasinda sürekli bir diyalektiğin var olduğunu gördü. Bu onun kilise (uzlaşmacı dini kurum), mezhep (uzlaşmayı reddeden kurum) ve mistisizm (dini kurumlardan çok dini coşkunun ortaya çıkardığı tecrübeyle ilgilenen bireylerin dinsel görüşü) tipolojisinin temeli haline geldi. 
Cemaatler, kültler ve kurum üstü dinler hakkında gerçekleştirilen müteakip araştırmalar tarafından geliştirilen bu basit şema, Batı'da dini kabullerin sınıflandırlması konusunda temel başvuru kaynağı haline geldi. Iddia edilenin aksine Protestantizmin modern dünya tarafından daha derinden etkilendiği sonucuna vardığı halde, Troeltsch, -arkadașı Weber ile birlikte- asketik kalvinizm ile kapitalizmin yükselişi arasında önemli bir ilişkinin varlığına inanmış görünüyordu. Bu seçkin bilim adamlarının en ayırt edici görüşleri, Troeltsch'un tarihselciliği ve Weber'in ideal tipçi, sosyolojik din yaklaşımıyd.

\subsection{Max Weber'in Katkıları}

Troeltsch kendi tarihselciliğinin ortaya çıkardığı teolojik sonuçlann derin şaşkınlığını yaşarken, Weber kendini "dini açıdan tarafsız" öncelikle "sıradan bir adam gibi" gerçeklerle cesaretle yüzleşmeye çalışan bir birey olarak nitelendirdi. Onun metodolojik açıdan olgulan ve değerleri birbirinden ayırması ("değer yargısından uzak sosyal bilim" gibi), antik İsrail araştırmalarında tanımladığ yaratan ve yaratılan arasındaki ilişkinin seküler değişimi gibi görünüyordu. Aym şekilde, onun "ahlaki kişilik" vurgusu, kendi ailesinin büyüsü bozulmuş Kalvinizminden derinden etkilenmiş gibiydi. Weber'in gerek siyasi bağlllkklanndan kaynaklanan varoluşçuluğu; gerekse sosyal hermönetiği, kalvinist geleneğin gönüllïlüğünü hatırlatıyordu. Özetle o, pek çok açıdan, kendine rağmen dindar bir düşünürdü. Din sosyolojisinde $o$, her şeyden önce, genelde dünyanun rasyonalizasyonunu ve özelde kapitalizmin yükselişini derinden etkileyen asketik Protestanlık teziyle bilinir.

Ondan öncekiler modern kapitalizmin özellikle Kuzey Avrupa'nın Protestan ülkelerinde geliştirildiğine dikkat çektiği halde, Weber bu ilişkiye sosyo-psikolojik bir açılklama getirdi. Weber'e göre Kalvinist kader öğretisi, Protestanlar -özellikle İngiliz Püritenler- arasında kendi kurtuluşlan konusunda derin bir endişeye yol açıyordu. Püritenler, refahun kendi tercihlerinin bir sonucu olduğuna inandiklan halde, kaderleri sanki buna bağlıymışçasına "kendi mesleklerinde" çalışmaya yöneliyorlardı. Başka bir ifadeyle, Püritenlerin dini kaygısı, dünyanın rasyonalizasyonunun ve büyü bozumunun ardında yatan irrasyonel dürtüydü. Tezinin karş̧laştırmalı araștırmalar tarafından kanıtlanabileceğine ya da doğrulanabileceğine inanan Weber, antik İsrail, Hindistan ve Çin ile ilgili bir dizi eser kaleme ald. Temel iddialan tarihçiler tarafından birer birer eleştirilmesine rağmen, Weber'in tezi, yaygın bir şekilde tartışlmaya devam etmektedir. O bugün bile sosyolojik ve tarihsel araştırmalara ilham vermeyi sürdürmektedir. Onun şekillendirdiği (meşruiyet, teodise, karizma, rutinizasyon vs. gibi) teorik yöntemlerin egemenliği, hala din sosyolojisinde çıraklı̆̆ın bir parçasıdır. 
Aynı dönemde araştırmalar yapan Durkheim ve Weber, din sosyolojisine, çok büyük olduğu kadar çeşitli katklarda bulundular. Durkheim, dinin toplumu bütünleştirici rolünü vurgularken, Weber öncelikle onun sosyal değişmedeki rolü üzerinde durdu. Durkheim'e göre kollektif "coşku", dini kavramlann ve gücün fors et origo'suydu (alfa, beta, gamasıydı veya abc'siydi). Weber'e göre ise, dini kavramlann ve sistemlerin gücü kurucu bireylerin ve peygamberlerin karizmasından kaynaklanyordu. Durkheim sosyolojik analizin "sosyal gerçekler" ile başladığına inand. Weber, sosyal eylemin yorumunun son tahlilde bireysel aktörlerin niyetinin anlaşlmasina bağlı olduğunu savundu. Durkheim, sosyoloji ve felsefeyi yeniden bir araya getirmeye çalş̧tı. Weber ise, onlann aynllğ 1 üzerinde durdu. Weber'in din hakkundaki yazılanında savunduğu "olan" ve "olması gereken" aynm, değerlerin felsefi açıdan hiçbir şekilde hakh gösterilemeyeceğine olan inancından kaynaklaniyordu. Yirminci Yüzyllın sonlannda sağda Herbert Marcuse'dan solda Leo Strauss'a kadar çeşitli düşünürler Weber'in eserlerinde derin bir nihilizmin yattı̆ını fark ettiler. Bu nihilizm onun sekülerleşme ve dünyanın büyü bozumunun Batı uygarlığının kaderi olduğuna dair romantik inancı içerisinde kökleşmiş gibi görünüyordu.

\subsection{Karl Marks'in Katkıları}

Din üzerine kısa, özlü ve çoğunlukla etkili yorumlanyla anulmasına rağmen, Karl Marks'ın din sosyolojisine doğrudan katkısı çok azdır. Onun bu alana gerçek etkisi, altyapı ve üstyapı kurumlannın karşlıklı etkileşimi ile ilgili teorisinin yaygınlik kazanmasıyla dolaylı bir şekilde olmuştur. Marks din, hukuk, siyaset ve ideoloji -bütün üstyapı kurumlan- arasındaki kültürel ve işlevsel benzerliklere dikkat çekti. Üstyapılann altyapı çalışanlanıun "üretim ilişkileri" tarafından belirlendiğini ısrarla vurguladiğı halde, Marks, dini kavramlann görece özerkliğini ve onların bağımsız değişkenler olarak işleyebileceğini fark etmiş görünüyordu. $O$, dinin bu dünya ile ilgili eskatolojik umutlannı devrimci praxis (eylem) ile gerçekleştirerek onu ortadan kaldırmanın yollann aradi. Bununla birlikte o, modem toplumdaki gerçek dünyevileștirici gücün devrimci proletarya değil, "dini sevginin en Tannsal coşkulannı... bencilce hesaplann buz gibi sulanna gark eden" burjuvazi olduğuna inanyordu.

Aydınlanmadan bu tarafa pek çok düşünür, genel bir "tarih sosyolojisi", yani tarihçinin ideografik sosyal değişme yaklaşımına karşı nomotetik bir alternatif geliştirmeyi denemiştir. Vico, Turgot, Adam Smith, Adam Ferguson, Lorda Kames (Henry Home), John Millar, Hegel, Herder, Tönnies ve diğer pek çoklan, geleneksel toplumdan aydınlanma uygarlığına geçişin 
karmaşıklğıı bazı temel dinamikler ya da her şeyi kuşatan Weltplan ile açiklamaya çalı̧̧ı.

Dini araşturmalara uygulanan bu şemalann çoğu son derece konjonktüreldi. Bu, özellikle, Herbert Spencer, John Lubbock ve E. B. Tylor gibi 19. yüzyl yazarlannın evrim teorileri açısından doğrnydu. Görüşleri sözde teorik olan evrimciler kısa sürede muazzam bir etki uyandırdı. Kendilerini kesinlikle evrimcilik akımyla ayn çizgiye dahil etmeyen Durkheim, Weber ve Tönnies gibi kişiler, buna rağmen açıkça evrimsel gelişim tipolojileri geliştirdiler. Marks'n tarih analizi, tarihi kendi iç ilişkileriyle açıklayan Hegelyanizme dayanan "diyalektik" bir sürece ve materyalist bir değişime göre ifade ediliyordu.

Birkaç burjuvazi kuramcisı Marksistlerin determinizmine ya da tarihçilerin pozitivizmine düşmeden sosyal değiş̧meyi tartışmaya çalıştı. Weber, ona göre tarihsel gelişmenin anahtar olan rasyonalizasyon süreci karşısında bir tür "yaklaşma-kaçınma" reaksiyonu sergiledi. Weber çoğu 19. yüzyl evrimcisinin saf iyimserliğine katılmadı̆ı halde, onun karmaşık, ideal tipçi kapitalizm yaklaşımunun ardinda bir tür ince, evrimci bir hareketin varlğ̆ hissedilebilir. Tönnies'in modern toplumu (Gesellshaft) zayflayan sosyal bağlarla karakterize eden yaklaşımına karşı temkinli bir çaba içerisinde olan Durkheim, modern toplumu bir arada tutan "organik dayanışma"nın geleneksel toplumdaki "mekanik dayanı̧̧ma" kadar etkili olduğunu savundu. 19. Yüzyl işgal eden konjonktürel gelişim şemalan din araşturmalarna uygulandı̆̆ında, talihsiz bir şekilde, din ile ilgili bütün sorunların, dinin evrim ya da tarihteki yeri sorununa indirgenmesi sonucunu doğurdu.

\subsection{Talcott Parsons'un Katkıları}

20. Yüzylda Talcott Parsons (1902-1979) sosyolojinin ilgisini genel sosyal eylem sistemleri içerisinde dinin konumuna yöneltti. Parsons, "Hobbesçu sosyal düzen sorunu"nu çözmek için, Durkheim, Weber, Freud, Cambridgeli ekonomist Alfred Marshall ve Harwardl biyokimyacı L. J. Henderson'un (Vilfredo Pareto'nun bir öğrencisi) görüşlerini birleştiren birkaç kuşatıcı sistem geliştirdi. Parsons, kültüre bir "sibernetik" egemenlik alanı ve dine bir a fortiori (evleviyet çn-) kazandırd. Eylem sistemi içerisindeki yüksek konumu sayesinde din, değerleri oluşturabilir, normlan şekillendirebiliir, sosyal rolleri öğretebilir ve toplum, kişilik ve davranış "sistemlern" ne kapsamlı bir rehberlik hizmeti sunabilirdi. "Değerlerin yaygınlaştırlması", "dinsel çoğulculuk", "dinin özelleşmesi", "liberalizm", "fundamentalizm" ve Neo-Kalvinist geleneğin "araçsalcı eylemciliğı" ile ilgili görüssleri, onun din ve kültür sosyolojisine daha önemli katkulan arasındayd.. Daha sonraki eserlerinde Parsons, sistemlerin yapısıyla daha çok, "eylem" in kendisiyle daha az meşgul 
oldu. Böylece, eylemi etkileyen nesnel faktörler daha çok, aktörün öznelliği daha az ilgi gördü. Onun himayesinde evrimciliğin revize edilmiş bir şekli kısa süreliğine yeniden gündeme geldi. "Neoevrimcilik" etnosentrizmin ve sosyal Darwinizm'in aşınlıklanndan uzak durmaya çalş̧tı̆̆ı halde, bilindiğgi gibi, onun temel kategorileri ve dinamikleri oldukça benzerdi: Uyum (adaptasyon), sosyo-kültürel farklllaşma ve bütünleşme. Parsons'un eserlerinin yaygın bir şekilde okunmaya başlandığı bu dönemin ardından öğrencisi Robert N. Bellah "Dini Evrim" adını verdiği bir deneme yazdı.

Parsons'un "kalıp sürekliliği (pattern maintenance)"nde dinin, fikirlerin ve değerlerin egemenliğinden dolayı, pek çoklan onu, bir idealist ve hatta statükonun ideolojik bir savunucusu olarak gördüğü için eleştirdi. Bazılan ise, ironik bir şekilde, onun sonraki eserlerini "davranısçlluğ" ve "pozitivizmi” nden dolayı eleştirdi. Her halükarda, yaşamının sonlanna doğru Parsons, "insanlığın sonu", "bozuk (telic) çevre" ve "beşeri durum" hakkındaki görü̧slerini daha özgürce ifade etmeye başladı. Bu görüşler, Bellah gibi bazı bilim adamlannun, Parsons'un sosyal bilim sınırlannın ötesine geçme çabasında olup olmadığın ya da bir teolog gibi davranıp davranmadığını sorgulamalanna yol açtı. Bütün bilimsel (ya da bilgince) titizliğiyle Parsons tıpkı Durkheim ve Bellah gibi- klasik sosyal düşüncenin kadim sorunlanyla yakından ilgilendi.

\section{6. Çăgdaş Etkiler}

Din sosyolojisi, edebi eleştiri (Kenneth Burke), semiotik ve hermönetik ile ilgili çağdaş araşturmalar (Hans-Georg Gadamer ve Paul Ricoeur) ve fenomenolojiden (Alfred Schutz) ciddi teşvik gördü. Edmund Husserl'ın "şeylerin aslına dönme" tavsiyesi, bazı sosyologlar tarafından bilgi kaynaklanın aktardığı bilgilerin daha ciddi bir şekilde ele alınmasına yönelik bir meydan okuma olarak yorumlandı. Böylece, fenomenoloji bazı çevrelerin kalitatif, humanistik sosyolojiye yeniden ilgi göstermelerine ilham vermiş gibi görünmektedir. Dini araştırmalar alanında fenomenolöi, oldukça farkl bir şekilde; (1) kilisevi-olmayan, değer yargısından uzak din yaklaşımına; (2) kültürler arası, karşılaştırmalı araştırmalara ve (3) gerek "ardındaki" Mutlak Hakikati gerekse onun sosyal yansımalan üzerindeki tüm dünyevi etkileri paranteze alan kutsala yönelik deskriptif, açıklayıcı olmayan bir yaklaşıma uygulandı. Bu fenomenolojik yaklaşım, çoğunlukla, ilahiyat dışındaki çevrelerde dini araştırmaların gelişimini kolaylaştıran din araştırmalanına yönelik seküler bir yönelimi cesaretlendirdi. Ancak fenomenolojinin "paranteze alma" yaklaşım, din üzerindeki seküler ve sosyal etkileri sınırsızca sorgulamaya başladığında, sosyolojik yönelim karşıtı bir durum ortaya çıkardı. 
Fenomenolojiyi dini arașturmalara tantan sosyologlandan birisi Peter L. Berger'dir. Berger'in çalışmalan Alfred Schutz'un sosyolojik fenomenolojisi ve Durkheim, Weber, Marx, George Herbert Mead ve W. I. Thomas gibi kișilerin eserlerinden etkilenmiştir. (Talcott Parsons, Robert N. Bellah, Clifford Geertz, Thomas Luckmann ve Arnold Gehlen gibi) diğer sosyal bilimcilerle birlikte, insanlığın kültürü -ve dini- genetik kusurlanum kapatmak için yarattığın savunan Berger, dini sembolleri, nesnelleştirme, somutlaştırma ve içselleştirme süreçleri tarafından üretilen psiko-sosyal yansıtmalar olarak görür. Din her şeyden önce, insan varlı̆ı̆ı meşrulaştıran ve ona sefaletini açıklayabileceği bir teodise sunan "bir mâkuliyet çatısı" olarak işlev görür. Hatta din, kutsal kitabın kehaneti gibi bazı istisnai durumlarda, sosyal yapılann yasallıktan-çıkanlmasına katkıda bulunabilir. Berger'in din teorisi, gerçekten çok kurgu olarak nitelendirilebilecek felsefi bir antropolojiye dayandığı halde, o, pek çok din sosyologunun yararlı gördüğü teorik bir dil geliştirmeyi başarmıştur.

Amerikan sosyolojisinde William Lloyd Wamer, Liston Pope, Robert ve Helen Lynd ve diğerleri tarafından yürütülen toplum araştırmalan, bize, din ve toplum ilişkileri konusunda çok şey öğretti. 1940'lara kadar Birleşik Devletlerde din sosyolojisinin kulavuz 1şılan sadece Durkheim ve Weber değil, aynı zamanda Herbert Spencer, Lester Frank Ward, William Graham Summer ve W. Robertson Smith'di. Bu düşünürlerin dine uyguladığ teori, teolojik bir yaklaşımın çok uzağındaydı. James $\mathrm{H}$. Leuba, The Belief in God and Immortality (1916) adlı kitabında, "büyïk sosyolog"lardan sadece \%19'u dine inanurken, din sosyolojisi pratisyenlerinden çoğunun inancını koruduğunu tespit etti. Bu bilim adamlannun çoğu, Sosyal Incil Hareketinin liberal taraftarlarydı. Daha sonralan, bu hareket, fundamentalizm, neo-ortodoksi ve seküler akademik camianın saldırlarına maruz kalırken, din sosyolojisine ilgi de giderek azalmaya başladı. (Manidar bir şekilde bu olay "değer yargısından uzak" sosyolojinin sosyal araştırmalardan kendini soyutlamasıyla yaklaşık aynı zamanda meydana geldi.) H. Richard Niebuhr'un The Social Sarnes of

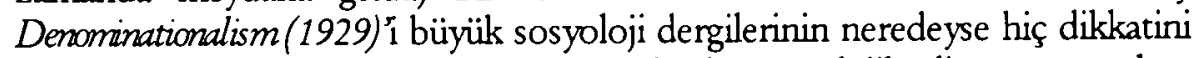
çekmedi. 1940'lara kadar Kuzey Amerika'da sosyolojik din araştırmalan, genellikle, yeni kurulan Katolik Sosyoloji Topluluğunun katkulanyla şekillendi. 1980'lerin ortalarına kadar Din Sosyolojisi Derneği, Katolik gruplan daha geniş ekümenik bir organizasyonunun içine çekti. Bilimsel Din Arașturmalan Topluluğu (Society for the Scientific Study of Religion) adı verilen başka bir mesleki teşekkül, alana daha istatistiksel ve bazen daha pozitivist yaklaşımyla ortak oldu. 


\section{Sonuçlar}

Yaklaşı 1920'lere kadar sosyoloji ve din antropolojisi modern sosyal bilimlerde bilindiği şekliyle kültür kavramın üretti. Çïnkü bu alanda ilgi daha sonralan dinden bizzat kültürün kendisine kaydı. Bugün din araştırmalan sosyoloji müfredat programinda daha az yer işgal etmektedir. Din modem sosyal teoriye çok önemli katkularda bulunduğu halde, dini bulgular, günümüzde çoğunlukla sadece genel teorilen açıklayıcı örnekler olarak kullanılmaktadır. Bu alanun öğrencileri enerjilerinin çoğunu korelasyon araştırmalanna ("din-ve- ..."), yani din ile sosyal hareketlilik, urksal önyargı, oy verme davranışı, boşanma, aile planlaması v.s. arasındaki karşullkh ilişkilerin incelenmesine harcamaktadur. Bu araştırmalar din ve toplum ilişkileri ile ilgili bilgilerimizi büyük oranda genişletirken, teorilerin inşasına çok az katkıda bulunmaktadır.

Din sosyologlan Troeltsch, Weber ve diğer önemli kuramclan "yeniden ziyaret etmektedir." Bu durum bu yazarlann eserlerindeki tipolojilerin önceki anlamlan ya da tarihsel bakış açısı korunmadan neredeyse bütünüyle tasfiye edilmeleri ile sonuçlanmaktadır. Bu alanın yoksullaştırildığının başka bir göstergesi, karşılaşturmali, kültürler arası araştırmalann ihmalidir. Bu ihmalle birlikte din sosyolojisi sadece "Huristiyan sosyologlar" in değil, aynı zamanda Hıristiyanlık araştırmalanını bir hizmetçisi haline gelmiştir. Bu disiplin Durkheim, Weber ve diğerlerinin (genelde felsefe ve özelde insan bilimleri alanında son derece başarul bilim adamlannun) çok sayda karşılaştırmalı araştırması sayesinde olgunlaşmaya başladığı halde, tarihselcilik, pozitivizm ve akademik yaşamın zorunluluklan, bu alandaki karşılaştırmalı araştırmalann kolaylıkla ölçülebilecek değişkenlerin ustalıkh bir manipülasyonuna indirgenmesine katkıda bulunmuştur. Tarihsel ve karşlaştırmalı derinlikten yoksun olunduğundan dolayı, din hakkında araştırmalar yapan birkaç sosyolog dışında, sosyoloji ya da dini araştırmalann bütününü ilgilendiren katkılar yaplamamaktadır. (Bellah, Berger, David A. Martin ve Bryan R Wilson gibi) bu alanda ün kazanmış söz konusu birkaç sosyolog, karşlaştırmalı ve tarihsel malzemeyi bol miktarda kullanmaktadır. Din araştırmalan, genel olarak, sosyal bilimlere çok şey borçlu olduğu halde, bugün -Clifford Geertz, Mary Douglas, Claude Lévi-Strauss ve Victor Turner- gibi yazarlann çalışmalan tarafundan temsil edilen- antropoloji, bizzat sosyolojiden daha büyük etkiye sahipmiş gibi görünmektedir.

Modern dönemde bazı bilim adamlan geleneksel sosyal düşüncenin olgular ve değerler arasında inşa etmiş olduğu köprüleri, yani Saint-Simon ve Comte'un dinsel mühendisliğini, Durkheim'in seküler ahlakçllğını ve Kuzey Amerika'da Hiristiyan sosyologlann ya da Fransa ve Belçika'da la sociologie 
religieuse taraftarlannın gerçekleştirdiği çeşitli uygulamalı araştırmalan yeniden inşa etmeyi denemektedir. Bununla birlikte, bugün din sosyolojisinin sımurlı kültürel öneminden dolayı, sadece birkaç yabancılaşmış teolog, Marx ile birlikte, toplumun kritiğinin dinin kritiği ile başladığın ifade edebilmiştir.

Geleneksel sosyolojinin din analizinde yer alıormuş gibi görünen kynikler okulunun etkisini azaltmak için Bellah, inançsızlĭgn daha liberal bir devaminı "sembolik realizm" olarak adlandırdı. Bu, aslında, Durkheim'in hiçbir dinin yanlş olmadığı ile ilgili görüsüne yeniden dönüldüğünün bir işareti olmuştur. Ne yazık ki, sembolik realizm, sadece, sosyal bilimler ve dini inancın zoraki ve özgün olmayan uzlaşısına katkıda bulunmuş gibi görünmektedir. Din sosyolojisinin ilahiyat disiplinleri arasındaki prestijinin hiçbir zaman bugünkünden daha yüksek olmayışı son derece şaşırtıcıdır. İlahiyatçılar, kutsal kitap üzerine araştırmalar yapan bilim adamlan ve Kilise tarihçileri -bazen bunu bütünüyle sindiremeseler ya da teorik gereklerini yerine getirmeseler de- sosyolojik bir yaklaşmala alanlanna yeniden dönmektedirler.

Köklen, idealizm, materyalizm, septisizm, edebi yergi ve romantik ve muhafazakar protesto gibi çok geniş alanlara uzandığından dolayı, din sosyolojisi, herkese her şeymiş gibi görünmektedir. En yüksek prestiji elde etmek için bazı yöntem bilimciler, bu alani, doğa bilimlerinin aksine, sonralan ayırt edici ve yanlışlayıcı özgün paradigmalann geliştirilmediği bir "multiparadigmalar" alanı olarak göstermektedirler. Bu durum, din sosyolojisinin konusunu büyük bir teorik yapıyla karşı karşıya getirmemekte, aksine sadece her tarafı gerilla bantlanyla sarılmış parça parça modellere ve "poli-metodik" taktiklere sahip savaşçlarla yüzleştirmektedir. Din sosyolojisi bir zamanlar kendisi için koyduğu hedefleri gerçekleştiremediğinden dolayı, bazlan, hakl. olarak onun, insan bilimlerinden ve onların ideografik yaklaşımlanndan nasıl ayruldığın merak etmektedir.

Bugün geleneksel sosyal bilim pozitivizminin geniş çapl eleştirisi, semiotik ve ortak kültürel sembollerin sibemetik kontrolü alanındaki yeni gelişmeler ve bireysel sosyal aktörün niyeti konusunda devam eden araştırmalar, din sosyolojisinde bazı ilginç değişimlerin önünü açabilir. Bu değişimler, bu disiplini, insan bilimleri ve dinler tarihi ile daha yakın ve daha verimli ilişkiler kurmaya sevk edebilir. Parsons, Bellah, Berger ve diğerlerinin çalışmalan, bizzat sekülerleşme teorisine yönelik daha sofistike ve daha az dogmatik bir tutum ortaya çıkarmıştır. Gelecekte, muhtemelen giderek artan sayıda araştırmacı, "dinler ortadan kaldırlamaz, sadece değiştirilebilir" diyen Saint-Simon'un kanaatlerini paylaşmış olacaktur. 


\section{BIBLIYOGRAFYA}

Din sosyolojisi konusunda Roland Robertson'un The Socidogical Interpretation of Religion' (New York, 1970) ve Thomas F. O'Dea'nun The Socidogy of Religion's (Englewood Cliffs, N.J., 1966) dahil, çok sayda iyi hazırlanmış giriș kitabı vardır. Joachim Wach'in The Socidogy of Religion'1 (1944; Chicago, 1962) alanın sınırlanı ansiklopedik, fakat başarlı bir şekilde çizmeyi denemektedir. Leo Strauss'un Natural Right and History (Chicago, 1953), Jacob Viner'in The Rde of Proridence in the Social Order (Princeton, 1972) ve Robert Bierstedt, Kenneth Bock ve Robert A Nisbet'in, editörlüğünü Thomas B. Bottomore'un yaptığı $A$ History of Sociological A nalysis (New York, 1978) adl eserdeki denemeleri, modern dönemin başlannda din ve toplum üzerine klasik sosyal düsünce ve spekülasyonun gelişimini ele alan çok sayıda eser arasındadır. Bu eserlerle karșilaştınldığında, Jan de Vries'in The Stucty of Religion: A Historical A pproadb'1 (New York, 1967), bizzat dinin analizi ile daha spesifik olarak ilgilenmektedir. Bu alandaki temel "klasik" metinlerin neredeyse tamamı İngilizce'ye çevrilmiştir. Bunlar arasında Émile Durkheim'in The Elementary Forms of Religious Life's (1915; yeni baskısı, New York, 1965) ve Max Weber'in üç eseri: The Protestant Ethic and the Spirit of Capitalism (1930; yeni baskıs1, London, 1974); The Sociology of Religion (Boston, 1963) ve From Max Weber. Essays in Sociology (1946; Oxford, 1967) saylabilir. Weber düşüncesine, doğru ve duyarh bir giriş, Reinhard Bendix'in Max Weber. An Intellectual Portrait (1960; Berkeley, 1977) başlıklı çalş̧masıdır. Emst Troeltsch'un The Social Teading of the Omistian Onondes'ü, (1931; Chicago, 1981, 2 cilt) hala tarihsel Hiristiyanlığ sosyolojik açıdan en iyi işleyen eserlerden biridir. Weber ve Troeltsch'un dikkat çektiği konular, $\mathrm{H}$ Richard Niebuhr'ün The Social Sorroes of Denominationalism (New York, 1929), Liston Pope'un Millhands and Preadhers: A Stucty of Gastonia (1942; New Hamshire, 1965) ve Gerhard Lenski'nin The Religious Factor. A Socidogical Stucty of Religion's Impact on Pditios, Ecomomics and Family Life'1 (Garden City, N.Y., 1961) olmak üzere üç Amerikan klasiği tarafından daha da geliştirilmiş ve değiştirilmiştir. Birleşik Devletlerde din sosyolojisinin gelişimi, "An Alliance for Progress: The Early Years of the Sociology of Religion in the United States," Socidogical A nalysis 42 (Spring 1981): 27-46 ve "After the Alliance: The Sociology of Religion in the United States from 1925 to 1949," Socidogical A nalysis 43 (Fall 1982): 89-204 başliklı makalelerde Myer S. Reed, Jr. tarafından ana hatlanyla tartışlmış̧ır. Robert N. Bellah'in Beyond Belief: Essays on Religion in a Post-Traditional Society (New York, 1970) bașluklı eseri, Çağdaş Amerikan Din Sosyolojisinde Post-Parsoncu eğilimin bir örneğidir. 